\title{
U.S. Feminists and Central America in the "Age of Reagan": The Overlapping Contexts of Activism, Intellectual Culture and Documentary Filmmaking
}

\section{Nick Witham}

\section{$\underline{\text { Abstract }}$}

This paper examines the attitudes of feminist activists, intellectuals and filmmakers to U.S. intervention in Central America during the 1980s. It traces the development of mutual intellectual and political sustenance between feminism and antiinterventionism, arguing that as feminist thinking bred new ways of approaching U.S. involvement in Central America, so anti-interventionist struggles bred new ways of thinking about women's activism. In making this point, the paper complicates narratives of the "age of Reagan" that overlook the persistence of left-wing politics during the 1980s. Instead, it argues that a specific form of international feminism enabled a community of activists to contribute to a vibrant culture of dissent that criticised conservative approaches to women's rights, and, at the same time, vigorously contested the interventionist foreign policy of the Reagan administration. 
In June 1985, an article by feminist activist Charlotte Bunch appeared in Sojourners magazine. Entitled "Global Feminism: Going Beyond Boundaries”, it led with a bold declaration: "the latest burst of energy and ideas for feminism is coming from the Third World." Bunch wrote that despite receiving a "bad press" since the heyday of second wave activism in the late 1960s, feminism had continued to grow:

Women's groups all over the world, but especially in the Third World, are taking up issues ranging from housing, nutrition and poverty to militarism, sexual and reproductive freedom, and violence against women...U.S.

feminists have to address what the United States does in the world, rather than simply feeling apologetic or defensive about it - and we have to look at how our work as feminists affects people's everyday lives. ${ }^{2}$

Similar reports of rapidly developing international links between activists circulated during the 1980s in a variety of contexts, along with arguments about the inherent internationalism of the feminist project itself. Their existence draws attention to an emerging interest amongst U.S. feminists in issues pertaining to international politics. Indeed, the period saw numerous First World women look to Third World national independence movements not only as sites of anti-colonial emancipation, but also of gender struggle. One example of this trend was Central America, where feminists began to identify with the cause of the revolutionary Sandinista government in Nicaragua and guerrilla movements in El Salvador and Guatemala, each of which was

Department of History and American Studies, Canterbury Christ Church University. Email: nick.witham@canterbury.ac.uk.

I am very grateful to Sharon Monteith, Tony Hutchison, Richard King, Nick Grant and two anonymous referees, who all provided insightful comments at different points during the completion of this article. I would also like to extend my thanks to Pamela Cohen, who generously answered my questions via email.

${ }^{1}$ Charlotte Bunch, "Global Feminism: Going Beyond Boundaries” (June 1985) in Karen Kahn (ed.), Frontline Feminism, 1975-1995: Essays from Sojourners’ First 20 Years (San Francisco: Aunt Lute Books, 1995) p. 454.

${ }^{2}$ Ibid. p. 456. 
fighting against counterrevolutionary forces backed by the U.S. government, whilst also prioritising women's issues. As they argued against U.S. intervention on behalf of repression in the region, American women's activists also felt that they were making a contribution to the growth of international feminism.

It is this historically specific confluence between two strands of radical political thought and culture - anti-interventionism and feminism - that this paper seeks to interrogate. To do so, it details the development of an international orientation within the U.S. feminist movement between 1975 and 1985, before examining several politicised texts that embodied this political synergy: the output of intellectuals Margaret Randall and Cynthia Enloe, and documentary films When the Mountains Tremble (Pamela Yates and Tom Sigel, 1983) and Maria's Story (Pamela Cohen and Monona Wali, 1990). In pursuing this interdisciplinary examination of the political culture of international feminism during the 1980s, the article demonstrates the overlapping contexts of activism, scholarship and filmmaking that existed within the 1980s U.S. left. It thereby highlights the manner in which new ways of conceptualising the discourses of anti-interventionism and feminism percolated activist culture, and helped to define the parameters of a movement that confronted Ronald Reagan's presidential administration and challenged its conservative policies in both the domestic and international spheres.

\section{Rethinking the "Age of Reagan": International Feminism in the 1980s}

Until recently, the historiography of the 1980s has paid scant attention to liberal and left wing politics during the decade. For example, many accounts focus on the period through the biographical lens of Ronald Reagan, whose name has become a synecdoche not only for his presidential term (1981-1989), but also for the decade as 
a whole, with historians referring to the "Reagan era" or the "age of Reagan". ${ }^{3}$ In these narratives, Reagan's electoral victories against Jimmy Carter in 1980 and Walter Mondale in 1984 represent the high tide of a brand of political conservatism that had its roots in the disintegration of the New Deal electoral coalition, negative responses to the social movements of the 1960s, and the rise of Sun Belt politics during the 1970 s. ${ }^{4}$ The dominant narrative of the 1980 s consequently characterises it as a period of decline for American liberalism: a decade of conservative political ascendancy, low taxes, deregulatory economic restructuring, and the dramatic decline in the power of organised labour, not only in the U.S., but across the industrialised world..$^{5}$

In most of these accounts, the left is virtually nowhere to be seen. To an extent, this is understandable. Compared to the 1930s and the 1960s, to give two obvious examples, progressive political activism was relatively marginalised during the 1980s. But this fact did not prevent a number of vibrant social movements from emerging during the decade, centring on issues as diverse as nuclear disarmament, the HIV-AIDS epidemic, anti-apartheid activism, and opposition to U.S. intervention in Central America. Several recently published histories of post-1960s American politics

\footnotetext{
${ }^{3}$ Daniel T. Rodgers has recently noted the inadequacy of such a focus on Reagan: "Divided, not unitary government was the rule in the last quarter of the century... The age was not Reagan's in remotely the same way that the 1930s were Roosevelt's. If we are to look for clearer historical fault lines, we must look elsewhere than to presidential elections." See Daniel T. Rodgers, Age of Fracture (Cambridge, MA: Belknap Press, 2011) p. 3.

${ }^{4}$ See, for example, Michael Schaller, Reckoning with Reagan: America and its President in the 1980s (Oxford: Oxford University Press, 1992); Haynes Johnson, Sleepwalking Through History: America in the Reagan Years (New York: W.W. Norton \& Co., 2003); John Ehrman, The Eighties: America in the Age of Reagan (New Haven: Yale University Press, 2005); Gil Troy, Morning in America: How Ronald Reagan Invented the 1980s (Princeton: Princeton University Press, 2005); Robert M. Collins, Transforming America: Politics and Culture During the Reagan Years (New York: Columbia University Press, 2007); Michael Schaller, Right Turn: American Life in the Reagan-Bush Era, 19801992 (Oxford: Oxford University Press, 2007); Sean Wilentz, The Age of Reagan: A History, 19742008 (New York: Harper Perennial, 2009).

${ }^{5}$ Bruce J. Schulman, "The Reagan Revolution in Perspective: Conservative Assaults on the Welfare State Across the Industrialised World" in Richard S. Canley (ed.), Reassessing the Reagan Presidency (Lanham: University Press of America, 2003); Kimberley R. Moffitt and Duncan A. Campbell (eds.), The 1980s: A Critical and Transitional Decade (Lanham, MD: Lexington Books, 2011).
} 
and society, as well as a number of more specific studies of political activism in the period, have begun the process of tracing the development and impact of these oppositional movements: notable examples include Robert Subrug's Beyond Vietnam (2009), Simon Hall’s American Patriotism, American Protest (2010) and Bradford Martin's The Other Eighties (2011). ${ }^{6}$ This important research is part of what Julian E. Zelizer has described as a "new wave" of historical scholarship on the history of American conservatism that is developing "a historical narrative about the divisions, oppositions, struggles and compromises" that conservatives battled with during the 1970s and 1980s. ${ }^{7}$ As Kim Phillips Fein has recently argued in the Journal of American History, this type of scholarship should help us to think of the "Reagan era" as "a moment of sustained conflict" between liberal and conservative interests, during which the left "helped to determine the course of events" even though the period "often seemed dominated by the right." 8

This interpretive scheme is as relevant to Central America activism as it is to any of the decade's social movements. As Roger Peace has shown in an important

\footnotetext{
${ }^{6}$ For broader studies, see Max Elbaum, Revolution in the Air: Sixties Radicals Turn to Lenin, Mao and Che (London: Verso, 2002); Van Gosse and Richard Moser (eds.), The World the Sixties Made: Politics and Culture in Recent America (Philadelphia: Temple University Press, 2003); Philip Jenkins, Decade of Nightmares: The End of the Sixties and the Making of Eighties America Oxford: Oxford University Press, 2006); Simon Hall, American Patriotism, American Protest: Social Movements Since the Sixties (Philadelphia: University of Pennsylvania Press, 2010); Bradford Martin, The Other Eighties: A Secret History of America in the Age of Reagan (New York: Hill and Wang, 2011). See also chapters on the 1970s and 1980s in Doug Rossinow, Visions of Progress: The Left Liberal Tradition in America (Philadelphia: University of Pennsylvania Press, 2008); Christine Stansell, The Feminist Promise: 1792-Present (New York: The Modern Library, 2010); Michael Kazin, American Dreamers: How the Left Changed a Nation (New York: Knopf, 2011). For more specific studies of localised movements or those targeting specific issues, see Annelise Orleck, Storming Caesars Palace: How Black Mothers Fought Their Own War On Poverty (Beacon Press: Boston, 2005); Melani McAlister, "Suffering Sisters? American Feminists and the Problem of Female Genital Surgeries" in Michael Kazin and Joseph A. Martin (eds.), Americanism: New Perspectives on the History of an Ideal (Chapel Hill: University of North Carolina Press, 2006); Robert Surbrug, Beyond Vietnam: The Politics of Protest in Massachusetts, 1974-1990 (Amherst: University of Massachusetts Press, 2009); Jonathan Bell, California Crucible: The Forging of Modern American Liberalism (Philadelphia: University of Pennsylvania Press, 2012).

7 Julian E. Zelizer, "Rethinking the History of American Conservatism" in Reviews in American History 38:2 (June 2010) p. 387.

${ }^{8}$ Kim Phillips Fein, "Conservatism: A State of the Field" in Journal of American History 98:3

(December 2011) pp. 740-741.
} 
study of Nicaragua-centred activism, solidarity networks and anti-interventionist groups countered the Reagan administration's attempts to acquire support for its policies by launching a "tenacious, grassroots-based campaign" to end funding to the Contras and prevent a direct U.S. invasion of Nicaragua. Whilst not universally successful in these goals, Peace has shown that the movement "raised the political cost of a potential invasion." This meant that dealing with domestic opposition became a primary concern of policy-makers such as National Security Advisor Lt. Col. Oliver North, who identified anti-interventionism as a key obstacle to U.S. policy in Central America. ${ }^{9}$ To highlight the political agency of the movement in this way is not to argue that the 1980s was, in fact, an inherently liberal period in American history. However, it is to make the subtler point that the left was by no means invisible during this period, even if, on balance, it ended the decade in defeat.

It is the contention of this paper that an examination of the growth of internationalism amongst U.S. feminists adds a new strand to this emerging historiographical synthesis. However, it is first necessary to recognise that the 1980s was by no means the first period in which American feminism developed an international consciousness. For example, Bonnie S. Anderson has shown that significant contact took place between feminists in the U.S., Great Britain and Germany between 1830 and 1860 as they sought to intersect their activism with that of abolitionists and early socialists. ${ }^{10}$ Furthermore, Lucy Delap's analysis of early twentieth century avant-garde feminism demonstrates that a rich transatlantic tradition was revived as the politics of women's issues fused with modernist aesthetics. ${ }^{11}$

\footnotetext{
${ }^{9}$ Roger Peace, A Call to Conscience: The Anti-Contra War Campaign (Amherst: University of Massachusetts Press, 2012) pp. 3-5.

${ }^{10}$ Bonnie S. Anderson, Joyous Greetings: The First International Women's Movement, 1830-1860 (Oxford: Oxford University Press, 2000).

${ }^{11}$ Lucy Delap, The Feminist Avant-Garde: Transatlantic Encounters of the Early Twentieth Century (Cambridge: Cambridge University Press, 2007).
} 
Expanding beyond a purely transatlantic frame of reference, and towards a global one, scholars of twentieth-century African American women's history have also identified the existence of a core group of "transnational radical black females" who embraced pan-African politics and moved "outside of circumscribing national spaces" in a bid to link their opposition to U.S. racism, patriarchy and class exploitation to international struggles for decolonisation. ${ }^{12}$ In a similar fashion, the late twentieth century international feminists under examination here looked to Central America in order to take account of emerging political movements outside of the U.S.

In making this international “turn”, American women's activists were, at least in part, responding to the prominence of anti-feminist campaigns of various stripes during the 1970s. Part of the broader "backlash" against the political agendas of the Civil Rights movement and the New Left, this opposition to gender equality took a variety of forms. In response to the Supreme Court's 1973 ruling in Roe v. Wade that a woman's right to privacy as upheld by the Fourteenth Amendment extended to her decision to have an abortion, for example, activists opposed to the expansion of women's reproductive rights mounted a nation-wide campaign to overturn the decision, and, in some instances, attacked abortion clinics. The "Stop ERA" movement that coalesced around Phyllis Schlafly was another example of this antifeminist tendency, as were intense debates in the American public sphere about affirmative action and a woman's right to pursue a career. ${ }^{13}$ However, this conservative backlash did not cause the retreat of feminist politics: rather, activists

\footnotetext{
${ }^{12}$ Carole Boyce Davis, Left of Karl Marx: The Political Life of Black Communist Claudia Jones (Durham: Duke University Press, 2007) pp. 2-7. See also Erik S. McDuffie, Sojourning for Freedom: Black Women, American Communism, and the Meaning of Black Left Feminism (Durham: Duke University Press, 2011).

${ }^{13}$ On the relationship between anti-feminism and the New Right, see Rosalind Pollack Petchesky, "Anti-abortion, Anti-feminism and the Rise of the New Right" in Feminist Studies 7 (Summer 1981) pp. 246-267; Donald T. Critchlow, Phyllis Schlafly and Grassroots Conservatism: A Woman's Crusade (Princeton: Princeton University Press, 2005); Ronnee Schreiber, Righting Feminism: Conservative Women and American Politics (Oxford: Oxford University Press, 2008).
} 
developed new strategies and found new problems with which to engage. These included initiatives as diverse as the formation of political action committee EMILY's List, and the promotion of Women's Studies as an academic discipline in order to harness the intellectual power of feminist critique. ${ }^{14}$ Whilst these essentially domestic dimensions of post-1960s U.S. feminism have garnered some scholarly attention, it is also important to understand the developing focus amongst women's activists on international politics during the 1980s. This process involved the internationalisation of feminist discourse in order to contextualise the domestic experience of antifeminist backlash, and to argue that American women's issues were, in a variety of ways, linked to those in the Third World. This article consequently focuses on the importance of Central America as an issue in the radicalisation of women's activists in the U.S. in order to add an important dimension to the study of feminism in the “age of Reagan".

During the period 1975-1985, for example, the establishment by the United Nations of an International Decade for Women tapped into a mind-set amongst feminist activists that emphasised, in the words of historian Christine Stansell, "the idea of a cosmopolitan body of women whose loyalties to the sex transcended their national identities." 15 As a part of the Decade for Women, a series of international conferences took place, allowing representatives of nation-states and nongovernmental organisations to meet and discuss the issues that faced women throughout the world. In 1975, the first International Women's Conference took place in Mexico City, setting out a "World Plan of Action" that aimed towards "full gender

\footnotetext{
${ }^{14}$ Sara M. Evans, "Feminism in the 1980s: Surviving the Backlash" in Gil Troy and Vincent J. Cannato (eds.), Living in the Eighties (Oxford: Oxford University Press, 2009) pp. 89-92.

${ }^{15}$ Stansell, op. cit. pp. 355-356. On the UN efforts to develop an international community of feminist activists, see Jocelyn Olcott, "The Battle within the Home: Development Strategies and the Commodification of Caring Labors at the 1975 International Women's Year Conference" in Leon Fink (ed.), Workers Across the Americas: The Transnational Turn in Labor History (Oxford: Oxford University Press, 2011).
} 
equality and the elimination of gender discrimination; the integration and full participation of women in development; and an increased contribution by women towards strengthening world peace." 16 Another meeting was held in Copenhagen in 1980, but perhaps the most significant event was the Third International Women's Conference held in Nairobi, Kenya to mark the culmination of the Decade for Women in 1985. According to a report on the event that appeared in U.S. journal Feminist Studies, activists came away from Nairobi having discussed the practical and theoretical issues underpinning international feminism, concluding that: "rethinking feminism beyond sexual egalitarianism... has become a central task for many within the North American feminist movement."17

This urge to take feminism "beyond sexual egalitarianism" was represented in prominent works by women of colour such as Angela Davis and Gloria Anzaldúa that were published during International Women's Decade, which emphasised the global dimensions of feminist struggle, as well as the important intersections between gendered, racial, ethnic and class oppressions. ${ }^{18}$ A particularly notable example of this tendency was feminist theorist bell hooks's book Ain't I a Woman (1981), which argued that African American women had been side-lined by both the patriarchy of the Black freedom struggle and the racism of the liberal feminist movement, before suggesting that "our struggle for liberation has significance only if it takes place within a feminist movement that has as its fundamental goal the liberation of all people." ${ }^{19}$ In making this argument, hooks was building on a history of

\footnotetext{
16 "First World Conference on Women" < http://www.un.org/en/development/devagenda/gender.shtml> (accessed 3 April 2012).

17 "Nilüfer Çağatay, Caren Grown and Aida Santiago, “The Nairobi Women's Conference: Toward a Global Feminism?” in Feminist Studies 12: 2 (Summer 1986) p. 405.

${ }^{18}$ See, for example, Angela Davis, Women, Race and Class (New York: Random House, 1981); Cherrié Moraga and Gloria Anzaldúa (eds.), This Bridge Called My Back: Writings by Radical Women of Color (Watertown: Persephone Press, 1981).

${ }^{19}$ bell hooks, Ain't I a Woman: Black Women and Feminism (London: Pluto Press, 1981) p. 13.
} 
internationalism amongst women of colour that was a persistent feature of their political activism, especially since the Black and Chicano nationalist movements of the 1960s and 1970s developed strong connections to women and men struggling against colonialism in Africa, Latin America and Asia. ${ }^{20}$ In this sense, women of colour developed an internationalist consciousness much earlier than their counterparts in the white, middle-class women's movement, and therefore acted as a kind of vanguard, leading the mainstream U.S. feminist movement towards and engagement with the Third World in the 1980s.

Women's activists consequently reoriented themselves towards universalist women's issues in the Third World, such as reproductive rights and genital mutilation. ${ }^{21}$ However, they also looked towards specific national liberation struggles for inspiration, especially those taking place in the United States' "back door":

Central America. The rest of this article examines the manner in which the Nicaraguan, Salvadoran and Guatemalan revolutions influenced the thinking of U.S. women's activists about both feminism and anti-interventionism. It therefore focuses explicitly on the attitudes and activism of North American feminists, rather than their Central American counterparts. In doing so, it fleshes out the importance of intervention in Central America in the radicalisation of U.S. feminists during the 1980s, as well as highlighting the contributions made by intellectuals and filmmakers to the culture of activism that emerged out of the anti-interventionist movement.

\footnotetext{
${ }^{20}$ On the internationalism of the post-1945 Black left, see Cynthia A. Young, Soul Power: Culture, Radicalism and the Making of a U.S. Third World Left (Durham, NC: Duke University Press, 2006). On Chicana feminism, see Alma M. Garcia, "The Development of Chicana Feminist Discourse, 19701980 " in Gender and Society 3:2 (June 1989) pp. 217-238.

${ }^{21}$ On the subject of genital mutilation, see Melani McAlister, "Suffering Sisters? American Feminists and the Problem of Female Genital Surgeries" in Michael Kazin and Joseph A. Martin (eds.), Americanism: New Perspectives on the History of an Ideal (Chapel Hill, University of North Carolina Press, 2006).
} 
Intellectual Activism: Margaret Randall and Cynthia Enloe

In the aftermath of the 1979 Nicaraguan revolution, in which female guerrillas had participated on an equal footing with men, the Sandinista government enacted a number of measures improving the status of women in the country, including the formation of an Office of Women to provide advocacy on a variety of issues. ${ }^{22}$ As queer historian Emily Hobson has shown, these developments meant that the revolution appeared to activists in the U.S. as, "the most explicitly pro-feminist national liberation movement of the post-war era, one that offered reconciliation between the goals of anti-imperialist struggle and women's liberation." ${ }^{23} \mathrm{~A}$ relationship of mutual intellectual and political sustenance therefore developed between the two movements: as feminist thinking bred new ways of approaching U.S. involvement in Central America, so anti-interventionist struggles occurring outside the U.S. bred new ways of thinking about women's activism.

These advances can be illustrated in more detail through examination of the 1980s output of poet and oral historian Margaret Randall, and international relations scholar Cynthia Enloe. Born in 1936, Randall spent the late 1950s and early 1960s working in avant-garde literary and artistic circles in New York before experiencing the turbulence of 1968 in Mexico City. As a consequence, her political development was intimately linked to the second wave of U.S. feminism that developed during the late 1960s. ${ }^{24}$ She moved to Cuba in 1969 , before relocating to Nicaragua in 1980 , where she stayed until 1984. At the start of her career, Randall developed a reputation both as a poet and an editor of the transnational New Left literary journal El Corno

\footnotetext{
${ }^{22}$ Norma Stoltz Chinchilla, "Revolutionary Popular Feminism in Nicaragua: Articulating Class, Gender and National Sovereignty" in Gender and Society 4:3 (September 1990) pp. 370-397.

${ }^{23}$ Emily K. Hobson, "Imagining Alliance: Queer Anti-Imperialism and Race in California, 1966-1990" $\mathrm{PhD}$ dissertation (University of Southern California, 2009) p. 267.

${ }^{24}$ Randall has highlighted this link herself. See Margaret Randall, Gathering Rage: The Failure of Twentieth Century Revolutions to Develop a Feminist Agenda (New York: Monthly Review Press, 1992) p. 16.
} 
Emplumado ${ }^{25}$ However, by the 1980s she had shifted orientation: starting in Cuba in the late 1970s and continuing throughout her time in Nicaragua, Randall conducted workshops that aimed to teach ordinary people, especially women, to record oral testimony in order to develop popular, self-authored historical narratives. ${ }^{26}$ The workshops resulted in a number of edited collections seeking to give Cubans and Nicaraguans ignored by "official histories" the space to document their everyday experience. For example, Sandino's Daughters (1981), which contained the testimony of women who had taken up arms with the FSLN during the Nicaraguan revolution, was intended to document "a different kind of history: women speaking for themselves about their experiences as women, and at the same time analysing the process of political development in their own country."27

Sandino's Daughters, along with several comparable collections Randall edited during the $1980 \mathrm{~s},{ }^{28}$ acted on the proposition that "feminism is about memory, about re-inserting memory into history." ${ }^{29}$ At the centre of Randall's mission was an attempt to develop a form of historical documentation that would represent the subjective experiences of women's everyday lives and their own individual struggles against imperialism. In this way, Randall sought to build on second wave feminism's strategy of "consciousness raising", which formed the backbone of women's organising during the 1960s and 1970s by emphasising the political dimensions of

\footnotetext{
${ }^{25}$ Randall founded the journal in 1959 in an effort to bring Latin and North American literary cultures into conversation. Published in both Spanish and English, El Corno Emplumado consequently printed a mixture of poetry, prose, and letters in the hope of fostering a transnational, revolutionary literature. See Dan Georgakas, "New Left Literature" in Mary Jo Buhle, Paul Buhle and Dan Georgakas (eds.) The Encyclopedia of the American Left (Oxford: Oxford University Press, 1998) p. 552.

${ }^{26}$ John Beverley, Testimonio: On the Politics of Truth (Minneapolis: University of Minnesota Press, 2004) p. 99.

${ }^{27}$ Margaret Randall (ed.), Sandino's Daughters: Testimonies of Nicaraguan Women in Struggle (Vancouver: New Star Books, 1981) p. i.

${ }^{28}$ See, for example, Margaret Randall (ed.), Inside the Nicaraguan Revolution: The Story of Doris Tijerino (Vancouver: New Star, 1978), and Margaret Randall (ed.), Cuban Women: Twenty Years Later (New York: Smyrna Press, 1980).

${ }^{29}$ Randall, Gathering Rage p. 35.
} 
"personal experience" and "self scrutiny". The formation of consciousness raising groups and the organisation of "speak outs" provided women with situations in which they could recount individual experiences of rape, violence and abuse, thus "placing accounts of women's lived experiences at the core of the feminist project." 30 Randall's approach to oral history can consequently be viewed as part of a broader development within the North American leftist imagination, in which Central America solidarity became a discourse that, at the same time as it protested U.S. intervention on behalf of the region's counter-revolutionary forces, also meshed with the conception that "the personal is political" to promote a feminist politics of memory.

This politicised conception of history was also important because of the relatively traditional and gendered analysis of Central American politics produced by much of the U.S. left during the 1980s. For example, prominent revisionist historians such as Gabriel Kolko and Walter LaFeber paid close attention to the region during the decade, arguing that the American public was poorly informed about the revolutions that were taking place there, and consequently suffering from a "crisis in historical perspective." ${ }^{31}$ Furthermore, noted linguist and public intellectual Noam Chomsky authored a critical examination of U.S. policy in the region and embraced a radical anti-interventionist stance. ${ }^{32}$ However, these prominent and widely discussed analyses did not engage the issue of gender, either in relation to the Nicaraguan,

\footnotetext{
30 Tasha N. Dubriwny, "Consciousness-Raising as Collective Rhetoric: The Articulation of Experience in the Redstockings' Abortion Speak Out of 1969” in Quarterly Journal of Speech 91:5 (November 2005) p. 401.

${ }^{31}$ See Gabriel Kolko, Confronting the Third World: United States Foreign Policy, 1945-1980 (New York: Pantheon Books, 1988); Walter LaFeber, Inevitable Revolutions: The United States in Central America (New York: W.W. Norton, 1984). For a discussion of revisionist historiography and the politics of intervention in Central America, see Nick Witham, "Confronting a "crisis in historical perspective': Walter LaFeber, Gabriel Kolko and the Functions of Revisionist Historiography During the Reagan Era" in Left History 15:1 (Fall/Winter 2010/2011) pp. 65-86.

${ }^{32}$ See Noam Chomsky, Turning the Tide: U.S. Intervention in Central America and the Struggle for Peace (Boston: South End Press, 1985).
} 
Salvadoran and Guatemalan revolutions themselves, or as it pertained to U.S. intervention and its impact on Central American society. Randall's attempt to forge a feminist politics of memory can therefore be viewed not only as an effort to give Central American women the space they were not afforded in their own "official" national histories, but also as an attempt to counteract the lack of attention paid to women's lives in the historiography produced by the U.S. left itself.

Two years younger than Randall, Cynthia Enloe was born in 1938. She took an undergraduate degree at Connecticut College in 1960, and a PhD in Political Science at the University of California, Berkeley, which she completed in 1967. Whilst Enloe was involved in Berkeley's Free Speech Movement, she was only on the fringes of the developing Women's Movement, and has acknowledged that she did not even use the word "woman" in her doctoral dissertation, which focussed on multiethnic politics in Malaysia. ${ }^{33}$ However, as her career progressed Enloe became one of the leading practitioners and theorists of feminist International Relations scholarship. The shift towards feminism in Enloe's research occurred during the late 1970s and early 1980s, and resulted in the publication of her first explicitly feminist work, Does Khaki Become You? in 1983, the Preface to which claimed that:

So much of military history and current commentary on weapons, wars and defense spending is written as though women didn't exist...It seems to me that by revealing both how military forces have depended on women and have tried to hide that dependence, we, as women, can expose a vulnerable side of the military which is often overlooked. ${ }^{34}$

\footnotetext{
33 "Interview with Professor Cynthia Enloe" in Review of International Studies 27:4 (October 2001) pp. 651-652.

${ }^{34}$ Cynthia Enloe, Does Khaki Become You? The Militarization of Women's Lives (Boston: South End Press, 1983) p. v.
} 
The book included discussion of the militarisation of prostitution, military wives, and the role of nurses in modern militaries. However, its most significant contribution in the context of this paper was Enloe's examination of the role of women in national liberation armies, in particular that of Nicaragua. She began by posing a question: "To what extent does participation in insurgent anti-state military forces emancipate women?"35 The answer, in the case of Nicaragua at least, was by no means simple. Whilst Enloe found evidence to suggest that women saw their active involvement in the Sandinistas' guerrilla campaigns as a means by which they could "change relations between women and men in Nicaragua," she also worried that the postrevolutionary Nicaraguan army was maintaining the traditional sexual division of labour by reverting to a "masculine state-authorised institution." ${ }^{36}$ In making this point, she emphasised that although the feminist agenda was advanced in certain important ways, many Nicaraguan women were concerned with the on-going patriarchy of the Sandinistas as the revolutionaries pursued their primary goals of land redistribution and the defeat of the Contras.

In 1985, Enloe published an article in Radical America entitled "Bananas, Bases, and Patriarchy: Some Feminist Questions About the Militarization of Central America." It argued that the relationships of dependency that characterised the international political economy were more gendered than previous scholarship had acknowledged. Enloe suggested that this conclusion had a direct relevance to the Central America solidarity movement: "when we root our political organising in analyses which disregard gender, feminism can quickly get shrunk to a shadow of its formerly vibrant self." ${ }^{\text {"3 }}$ These arguments culminated in Bananas, Beaches, and Bases

\footnotetext{
35 Ibid. p. 160.

${ }^{36}$ Ibid. pp. 170-172.

${ }^{37}$ Cynthia Enloe, "Bananas, Bases, and Patriarchy: Some Feminist Questions About the Militarization of Central America" in Radical America 19:4 (July-August 1985) pp. 7-8.
} 
(1989), which stood as Enloe's first systematic attempt to formulate a feminist theory of international relations, and was published just as gendered analyses of world politics by scholars such as Carol Cohn, Jean Bethke Elshtain, Judith Hicks Stiehm and J Ann. Tickner, along with those of Enloe herself, entered the mainstream of the discipline. ${ }^{38}$ In the book's introduction, Enloe used the recently exposed Iran-Contra affair as a touchstone, considering what role women played in the scandal, as well as how it affected their everyday lives, not only in the U.S., but throughout the Third World. ${ }^{39}$ Again, then, analysis of a particular facet of U.S. intervention in Central America was used to demonstrate the ways in which the politics of antiinterventionism and feminism were mutually reinforcing. In spite of the obvious differences between Randall and Enloe - the first an activist and cultural worker favouring the political rhetoric of poetry and oral history, the second a professional scholar working within the disciplinary boundaries of the U.S. academy - their examples highlight the intersections between feminist intellectual culture and antiinterventionist activism during the 1980s, and demonstrate how the urge to internationalise women's political thinking created new and fruitful ways of conceptualising U.S. intervention in Central America.

\section{Documentary Politics and the Testimonio Narrative}

This type of political convergence also took place in several politicised documentary films produced during the 1980s. Writing in 1994, film scholar Paula Rabinowitz

\footnotetext{
${ }^{38}$ See Carol Cohn, "Sex and Death in the Rational World of Defense Intellectuals" in Signs 12(4) (1987) pp. 687-698; Jean Bethke Elshtain, Women and War (Chicago: University of Chicago Press, 1987); Judith Hicks Stiehm, Arms and the Enlisted Woman (Philadelphia: Temple University Press, 1989); J. Ann Tickner, Gender in International Relations: Feminist Perspectives on Achieving International Security (New York: Columbia University Press, 1992). For an overview of the field, see Eric M. Blanchard, "Gender, International Relations and the Development of Feminist Security Theory” in Signs 28:4 (2003) pp. 1289-1312.

${ }^{39}$ Cynthia Enloe, Bananas, Beaches, Bases: Making Feminist Sense of International Politics op. cit. pp. 7-11.
} 
described what she saw as a "puzzling contradiction" that emerged during the period: in spite of intense "political repression" by the New Right, during which public funding of the arts was markedly reduced, documentary filmmaking had exhibited an unexpected "renaissance". ${ }^{40}$ In making this point, Rabinowitz highlighted the fact that during the 1970s and 1980s, increasingly large numbers of activists made use of improved access to documentary filmmaking's means of production and distribution as constituted through the development of affordable, lightweight equipment and video technology - to make films that engaged with a variety of political issues. During the same period, widely distributed, prize-winning films such as Harlan County, U.S.A. (Barbara Kopple, 1976) and The Thin Blue Line (Errol Morris, 1988) demonstrated the potential impact and critical acclaim that could be acquired by politically minded documentary filmmakers.

Documentary film also played a significant role in the cultural life of the feminist and Central American solidarity movements. Two films that typify the relationship that developed between feminist filmmakers and anti-interventionist activists are When the Mountains Tremble (1983) and Maria's Story (1990). When the Mountains Tremble uses the narration of Rigoberta Menchú, an indigenous Guatemalan peasant-turned-guerrilla and a subsequent winner of the Nobel Peace Prize, to narrate the struggle of her people against the U.S.-backed Guatemalan armed forces. The film was the brainchild of a trio of American freelance filmmakers Pamela Yates, Tom Sigel and Peter Kinroy - who came together in 1980 to form the independent production company Skylight Pictures. It originated in a project undertaken by the group to make a set of documentaries for commercial network CBS. In 1982, two hour-long films entitled Central America in Revolt and Guatemala

\footnotetext{
${ }^{40}$ Paula Rabinowitz, They Must be Represented: The Politics of Documentary (London: Verso, 1994) p. 2.
} 
appeared as a part of the "CBS Reports" series. During the production of these programs, however, the crew collected a large amount of unused material, which they decided to draw on to make their own, feature length film that would eschew the format imposed by network television and consciously adopt a "partisan approach" to the history of U.S. involvement in Guatemala. ${ }^{41}$

Maria's Story chronicles the daily life of Maria Serrano, a mid-level guerrilla leader in the Salvadoran Farabundo Martí National Liberation Front (FMLN). The initial monies for the production came from the British television company, Channel 4, which allowed the crew to travel to El Salvador and shoot 68 hours of footage. ${ }^{42}$ However, on their return to the U.S. in June 1989, directors Pamela Cohen and Monona Wali still required $\$ 107,000$ to complete the film. The project was initially rejected for screening on PBS, and for over twelve months looked as though it might never be realised. ${ }^{43}$ However, further funding was eventually acquired from the New York State Council on the Arts, a body similar in make-up to the CPB that operated at the state rather than federal level, as well as the Women's Project and the Paul Robeson Fund.

When the Mountains Tremble and Maria's Story were therefore intended for screening on public television networks, which would offer access to a mass audience. However, both sets of filmmakers also recognised the importance of alternative distribution networks, and sought to collaborate with the Central America solidarity movement in order to establish viewers amongst this specific activist community. In a 1985 interview, for example, Pamela Yates suggested that she wanted When the Mountains Tremble to "help organise Americans to stop U.S.

\footnotetext{
${ }^{41}$ Alan Rosenthal, "When the Mountains Tremble: An Interview with Pamela Yates" in Film Quarterly 39:1 (Autumn 1985) p. 4.

${ }^{42}$ Christina M. Riley, “Maria's Story: A Question of Passion” in UCLA Film and Television Archive Newsletter (November/December 1990) p. 6.

${ }^{43}$ Rosenberg, “Maria's Story Untold...So Far" op. cit.
} 
intervention in Central America." ${ }^{44}$ With this strategic goal in mind, the film was distributed alongside another Skylight Pictures production, Nicaragua: Report from the Front (Deborah Shaffer, 1983). The two films were screened together in order to highlight the interconnections between revolutionary situations throughout Central America, because, as Yates pointed out: "Although a lot of people know that the United States is involved with Nicaragua, they don't know there is a war going on in Guatemala." 45 The film's credits thanked the Network in Solidarity with the People of Guatemala and the Committee to Aid Guatemalan Refugees, and it was advertised in the programme for the 1985 convention of the largest U.S.-based solidarity organisation, Committee in Solidarity with the People of El Salvador (CISPES), indications of their makers' connections with the Central America solidarity movement. $^{46}$

Maria's Story was also linked to the solidarity movement, via Camino Film Projects, an organisation established by Pamela Cohen and other activist-filmmakers in 1985 . The company was designed as "an independent entity aimed at producing documentaries about social change," 47 and was "committed to providing educational and organizing tools for solidarity and anti-intervention organizations. ${ }^{\text {48 }}$ Maria's Story was consequently made with the cooperation of CISPES, representatives of which helped its crew gain access to the FMLN ${ }^{49}$ CISPES networks throughout U.S. also screened the film, often with introductory speeches by representatives of the Salvadoran guerrillas, and Camino shared a percentage of the proceeds from each

\footnotetext{
${ }^{44}$ Ibid. p. 8.

${ }^{45}$ Rosenthal, "When the Mountains Tremble" p. 9.

${ }^{46}$ CISPES Conference Programme (25 May, 1985) p. 9, Committee in Solidarity with the People of El Salvador Records, Wisconsin Historical Society, M94-308: Box 1, Folder 3.

${ }^{47}$ Author's personal email correspondence with Pamela Cohen (August 28 2010).

${ }^{48}$ Pamela Cohen to CISPES (June 7, 1985) Committee in Solidarity with the People of El Salvador Records, Wisconsin Historical Society, M94-308: Box 1, Folder 3.

${ }^{49}$ Author's personal email correspondence with Pamela Cohen (August 28 2010).
} 
premiere with solidarity organisations that helped to sponsor the events. ${ }^{50}$ Both films were therefore used as "organising tools" within the solidarity movement, and helped to open up discursive spaces in which anti-interventionist and feminist political agendas could be brought into fruitful conversation.

The films did not have a significant impact within policy-making circles in the same way as bigger-budget dramatic pictures Under Fire (Roger Spotiswoode, 1983) and Salvador (Oliver Stone, 1986), both of which were given high profile screenings on Capitol Hill in an effort to boost support for anti-interventionism during the 1980s. However, the 1986 broadcasting of When the Mountains Tremble on public television caused a stir in the mainstream media when New York Times reviewer John Corry argued that:

the principal source of financing was the Corporation for Public Broadcasting, which operates with taxpayers dollars. Forget the political content of the documentary for now: America won't crumble because of agitprop. A better question is, why should such a vanity production be subsidised? It's like indulging children with toys. ${ }^{51}$

Corry's criticisms demonstrate that the impact of the film was felt beyond the important, yet relatively narrow, confines of the Central America solidarity movement. Indeed, despite being released seven years apart, When the Mountains Tremble and Maria's Story entered a media landscape defined by contestation over

\footnotetext{
${ }^{50}$ Author's personal email correspondence with Pamela Cohen (August 28 2010). Evidence of the manner in which Maria's Story was distributed can be found in Polemicist, a left-wing student journal with ties to CISPES that ran on the Austin campus of the University of Texas during the early 1990s. In May 1991, the journal advertised a screening of the film, and stated that "on opening night, Gladis Sibrian, a U.S. representative of the FMLN (and like Maria Serrano, a woman originally from rural Chalatanago) will speak." In its review of the film, New York-based radical weekly the Guardian advertised a CISPES/MADRE screening of the film at NYU scheduled for March 10 1991. See Scott Bradwell, "Maria's Story" in Polemicist 2:6 (May 1991) p. 10, and Lisa Maya Knauer, "Maria's Vivid View of Revolt" in Guardian (March 6 1991) p. S-8.

${ }^{51}$ John Corry, “A PBS Documentary on Guatemala" in New York Times (January 12 1986) p. C14.
} 
the legitimacy of politicised art forms. Was the representation by U.S. filmmakers of the lives of individual Central American women and the manner in which they were affected by U.S. intervention an inappropriate cause for filmmakers to take up and for federal or state bodies to fund? Or, were such perspectives on Third World revolutionary struggle an essential corrective to those provided by mainstream television reporting? These questions shaped the reception of the two films, just as their distribution blurred the line between documentary filmmakers' appeals to the divergent audiences provided, on the one hand, by the solidarity movement, and, on the other, by public television networks.

To appeal to these audiences by fusing the politics of anti-interventionism and international feminism into a potent mixture of propaganda and political filmmaking, When the Mountains Tremble and Maria's Story replicated the rhetorical strategies of the "testimonio narrative", a genre that rapidly rose to prominence in Latin American literary culture during the late Cold War. Literary critic John Beverley has defined the testimonio as:

a novel or novella-length narrative in book or pamphlet (that is, printed as opposed to acoustic) form, told in the first-person by a narrator who is also the real protagonist or witness of the events he or she recounts, and whose unit of narration is usually a 'life' or significant life experience. ${ }^{52}$

Further to these claims, Beverley notes that the author-narrators of testimonios tend to have political, rather than purely literary, ambitions for their texts, and that the

\footnotetext{
${ }^{52}$ John Beverley, 'The Margin at the Center: On Testimonio (Testimonial Narrative)' in Modern Fiction Studies 35:1 (Spring 1989) pp. 12-13.
} 
development of the form was closely linked to the rise of anti-imperialist national liberation struggles in Latin America after the Cuban Revolution of 1959. ${ }^{53}$

One of the genre's most notable early proponents was Rigoberta Menchú, who first published Ma Llamo Rigoberta Menchú Y Asi Me Nació La Concienca in 1983. The text was quickly translated into English and published as I, Rigoberta Menchú by London-based Verso Books a year later, and has since risen to prominence in the U.S. based primarily on Menchú's receipt of the Nobel Peace Prize in 1992, but also due to the significant controversy in literary and academic circles caused when the truth of its author's autobiographical claims were questioned by anthropologist David Stoll in 1999. ${ }^{54}$ However, in order to understand the context in which the text emerged, as well as its subsequent importance for When the Mountains Tremble, it is important to remember that upon its release, Menchú's book stood as "a call to conscience, a piece of wartime propaganda", designed to draw the attention of the world to atrocities being committed by the Guatemalan military, and reinforced by Ronald Reagan's policies towards Central America. ${ }^{55}$ Indeed, as Ana Patricia Rodriguez has noted, the text emerged as the most notable example of a much broader culture of "testimonial narrative textuality" that served as "a historiographic record of neo-colonialism" for communities throughout the isthmus, similar in technique and political intention to the work of Margaret Randall. ${ }^{56}$ When these factors are borne in mind, the contrapuntal structure of When the Mountains Tremble - in which shots of Menchú delivering her testimony in subtitled Spanish are interspersed with original

\footnotetext{
${ }^{53}$ Ibid. pp. 13-14.

${ }^{54}$ See David Stoll, Rigoberta Menchú and the Story of All Poor Guatemalans (Boulder: Westview Press, 1999). For a detailed summary of the imbroglio surrounding Stoll's book, see Arturo Arias (ed.), The Rigoberta Menchú Controversy (Minneapolis: University of Minnesota Press, 2001).

${ }^{55}$ Greg Grandin and Francisco Goldman, 'Bitter Fruit for Rigoberta' in The Nation (February 8 1999) p. 25.

${ }^{56}$ Ana Patricia Rodriguez, Dividing the Isthmus: Central American Transnational Histories, Literatures, and Cultures (Austin: University of Texas Press, 2009) pp. 76-77.
} 
documentary footage highlighting the history of late Cold War Guatemala - may be read as explicit markers of the film's links to the testimonio narrative. The interweaving of Menchú's personal story with a wider examination of Guatemalan politics also highlights her testimony's status as the story of an entire community, another consistent feature of the genre. Indeed, Menchú herself makes this point when she categorically states, "I'm going to tell you my story, which is the story of all the Guatemalan people.”

A similar rhetorical style is evident in Maria's Story. Along with interviews and conversations with her husband, the testimony provided by Maria serves to establish the details of her biography, and provides the film's voice-over narration. As its title suggests, Maria's Story intends to tell Maria's personal story, in which she bears witness to the realities of everyday life as an FMLN combatant. However, her account also stands for something larger, as she makes clear in her final dialogue with the camera:

The reason I decided to be a part of this film was to explain our reality to the North American people, and other people who may not understand it. In this revolution, as you can see, we all participate. So I feel a little embarrassed because I'm playing a role that belongs to everybody...We all work together, everyone, every minute of our life.

In tying their narratives to the formal conventions of the testimonio in such a way, When the Mountains Tremble and Maria's Story each focus on using the story of an individual woman to paint a broader political portrait of revolutionary struggle. What were the political implications of these narrative strategies? First, the foregrounding of female revolutionary subjectivity enacted by the films highlighted the manner in 
which they were consciously taking sides in a debate over U.S. counterrevolutionary intervention in Central America. Second, in adopting the rhetorical style of the testimonial genre, both films succeeded in opening up a discursive space in which the potential links between anti-interventionist and feminist political agendas could be articulated. ${ }^{57}$ This meant that Menchú and Serrano, as the primary subjects of When the Mountains Tremble and Maria's Story, were represented by their positions within the narratives of the two films as articulate subaltern subjects.

The pitfalls of drawing such a conclusion have been adequately highlighted by, amongst others, Gayatri Chakravorty Spivak, whose 1988 essay "Can the Subaltern Speak?”, provides a negative assessment of the ability of subaltern subjects (i.e. Menchú and Serrano) to provide authentic representations of themselves within the parameters provided by Western political discourse. ${ }^{58}$ In When the Mountains Tremble and Maria's Story, it is clear that Menchú and Serrano do not speak for themselves. Rather, they are represented on screen by U.S. filmmakers, who, no matter how sympathetically, sought to use their narratives to serve a political cause. Indeed, as Greg Grandin has suggested, Menchú had been unable to escape a similarly discrepant power relationship during the initial publication of her testimonio narrative: based on interviews conducted by Elizabeth Burgos-Debray and translated by Ann Wright, I, Rigoberta Menchú was, at best, “a composite of many people’s work abridging, resequencing, and editing the raw material of Menchú's story".59 Furthermore, the focus of the two films on strong, articulate protagonists was by no

\footnotetext{
${ }^{57}$ In making this point, it is necessary to note the "strong female-gender orientation" of the testimonial genre, and the manner in which it has been used by Latin American authors to document the politics of sexual as well as neocolonial oppression. On this topic, see Linda S. Maier, 'The Case For and Case History of Women's Testimonial Literature in Latin America' in Linda S. Maier and Isabel Dulfano (eds.), Woman as Witness: Essays on Testimonial Literature by Latin American Women (New York: Peter Lang, 2004) p. 2.

${ }^{58}$ Gaytari Chakravorty Spivak, 'Can the Subaltern Speak?' in Cary Nelson and Lawrence Greenberg (eds.), Marxism and the Interpretation of Culture (Urbana: University of Illinois Press, 1988) p. 288.

${ }^{59}$ Greg Grandin, Who is Rigoberta Menchú? (London: Verso, 2011) p. 15.
} 
means unique within contemporaneous U.S. political filmmaking. For example, Roger Spotiswoode and Oliver Stone, the directors of the mainstream, yet decidedly antiinterventionist Under Fire and Salvador, both chose to centre their stories around the experiences of male heroes in order to romanticise their positions within the drama of the revolutions taking place in Nicaragua and El Salvador.

The use of Menchú and Serrano also highlights the manner in which indigenous political "martyrs" are regularly used by solidarity organisations to draw activists into sympathy with their causes. As Larry Reid has argued, this form of "solidarity martyrdom" helps to explain why individuals devote time and effort to "the cause of people with whom they have nothing obvious in common." ${ }^{.60}$ At the same time, though, the strategy also risks stereotyping indigenous politics and distorting Northern activists' understandings of Southern societies: "unless people are taken beyond the initial exposure to a martyr...the martyr figure becomes counterproductive." ${ }^{\circ 1}$ It is therefore necessary to recognise that, at least in part, the testimonio style used by the filmmakers emphasised the martyrdom of Menchú and Serrano, and was adopted in order to avoid challenging U.S. audiences in the habit of viewing this type of narrative, rather than out of fidelity to a distinctly Central American form of storytelling.

Nonetheless, it was in their representation of the lives of individual Central American women that the directors of When the Mountains Tremble and Maria's Story believed the power of political persuasion resided: as Pamela Cohen has argued, the "personal portrait" provided by Maria's Story was praised by solidarity activists because of the way it "helped them reach a broader circle of folks in their education,

\footnotetext{
${ }^{60}$ Larry Reid, "Menchú Tum, Stoll and Martyrs of Solidarity" in Development in Practice 11:1 (February 2001) p. 78.

${ }^{61}$ Ibid. p. 84.
} 
outreach and advocacy work." ${ }^{62}$ Whilst their consciously politicised narrative styles did not escape mainstream convention, and they were not able to overcome the contradictions inherent in providing representations of subaltern subjects, When the Mountains Tremble and Maria's Story were nonetheless able to successfully adapt the form of documentary filmmaking to bring the observations of feminism and antiinterventionism together to form a powerful ideological combination. Rather than being perfectly accurate representations of the lives of Central American female revolutionaries, then, the films are important because of what they reveal about the North American feminist imaginary as it adapted to the international political situation in the "age of Reagan".

\section{$\underline{\text { The Female Revolutionary Experience }}$}

Discussing the manner in which her film deals with feminist issues, Pamela Cohen has noted that:

Maria's Story, by virtue of its subject, is a feminist film. We made a very conscious choice that our protagonist be a woman. We, the producers and directors, are women. We never waved it as a flag, but of course it was an intention of ours. Maria, at that time, wasn't thinking of herself as a feminist, but of course in our interviews we raised questions about her being a woman and about being in the position she was in the FMLN. ${ }^{63}$

Cohen's point highlights a common trait linking When the Mountains Tremble and Maria's Story: whilst neither of the films' protagonists self-identify at any point as feminists, their stories were filmed by documentary filmmakers with political

\footnotetext{
${ }^{62}$ Author's personal email correspondence with Pamela Cohen (August 28 2010).

${ }^{63}$ Ibid.
} 
intentions informed by the political culture of international feminism. As such, it is important to examine how the two films were able to capitalise on the formal and rhetorical strategies outlined in the previous section to articulate a distinct brand of feminist anti-interventionism.

When the Mountains Tremble dramatises the difficulties faced by women under a military regime through the representation of a "Miss Guatemala Pageant", at which a group of women clad in either Wrangler denim or revealing swimsuits are paraded in front of a crowd of smartly dressed men. As the contestants come onto the stage, a male compere tells the audience: "The Guatemalan woman greets you with love and devotion", before asking several of the women questions as a part of the competition. After this, two participants arrive on stage in the traditional clothes of Guatemalan indigenous groups and read out patronising details about the groups they represent. The women are very clearly sexualised, and, in the case of those in native dress, take part in the eroticisation of indigenous culture. To provide a contrast to the beauty pageant, the film immediately cuts to an interview with an indigenous woman, who, as if in direct response to the spectacle, indignantly states, "The government uses us when it is in their interest. They exhibit us in our native dress as though we were in a zoo...the army and the rich consider us unskilled brutes who don't know anything." In dramatising the contrast between the high-spirited scenes of the beauty pageant and the woman's raw anger, the film therefore combines a critique of the manner in which Guatemalan culture has become sexualised by American business presence: in having integrated the most superficial of Northern rituals (the beauty pageant) to give pleasure to their U.S. patrons, the country's elite have subordinated women and indigenous communities to the status of spectacle, trapped in this position by a repressive political system. 
This point is reinforced later in the film when a group of indigenous women are shown talking to a guerrilla leader. He asks those who have been raped by members of the armed forces to raise their hands, and the majority do so, highlighting the vicious basis of military rule. Maria's Story also dramatises a similar ideological critique of the Salvadoran army. Early in the film, for example, Maria discusses the death of her eldest daughter Ceci, and confides to the camera that at the moment she realised Ceci was dead: “I've never felt so much rage. Not so much because they killed her, because we are making a war, them against us, us against them. But because after killing her, they stripped and mutilated her." In these representations of the armed forces, both films portray the ruling order as viciously sexist, and inherently tied to a system of patriarchy that views rape and gruesome violence as a legitimate means of waging war.

When the Mountains Tremble and Maria's Story also demonstrate the impact of women's domestic labour in bringing them to political consciousness. Reflecting on her life before becoming politically active, Maria states:

I was a peasant, the wife of a peasant farmer. I did house work: grind corn, iron, wash, sow, go to mass. But that life allowed me to see many unjust things. The poor, always forgotten, and all their possibilities limited. Some people with absolutely nothing. That inequality and poverty is what made me decide to leave that life.

After experiencing this form of work, and forging a sense of solidarity with other poor women, Maria describes how she decided to join a peasants' union in order to bring about political and economic change. In detailing the life of her mother in When the Mountains Tremble, Rigoberta Menchú tells a similar story: "My mother had to go to work as a servant in the capital to support our family. In the city she experienced even 
worse discrimination than in the country. But there she also met poor non-Indians whose living conditions were terrible, just like ours." This process of coming to consciousness led Menchú's mother to join with her fellow servants in an attempt to organise their opposition to the ruling order: again, then, direct experience of the traditional life of peasant women was a necessary step in the journey towards the realisation that society could be changed for the better through resistance to the status quo. Whilst neither of these stories was told in the explicit language of feminism, feminist ideological observations were essential in order for the filmmakers to frame them in such a way as to emphasise the important gender dimensions of the transformations that took place in the lives of their subjects.

In a similar vein to the work of Cynthia Enloe, both films also explore the impact of guerrilla warfare on the lives of female combatants. The final third of When the Mountains Treble, for example, is filmed almost entirely in a Guatemalan National Revolutionary Unity (URNG) camp, and it soon becomes clear that women are an important sector of its community. At one point, a female guerrilla speaks to a large group of women and argues that their participation in the revolution is just as important as those of their husbands, sons and brothers:

Compañeros, we are far from our homes. The children are suffering the most. So we must fight for our kids. The men have to join the war, and the women have to join the war. Follow the example of our many fighting friends. We women must not stay at home. We can do more than make tortillas. Now is the time for us women to use our brains.

These arguments for gender equality are backed up by the comments of two young URNG recruits, who affirm that their male counterparts treat them as equals and that 
they consequently feel a sense of sexual liberation through their participation in the revolution. One even goes so far as to suggest that this could be a permanent feature of life in the new Guatemala: “up here, we've learned better ways to live, and when we win, and go back to our villages, we'll live even better, since it will be easier there." In presenting this point of the view, directors Yates and Sigel engage the question, posed by Enloe in Does Khaki Become You?, of whether or not gender equality amongst revolutionaries can be sustained in the aftermath of a successful guerrilla war, and, by offering a tentatively positive answer, posit the Guatemalan struggle as one not only against social inequality and U.S. interventionism, but also against patriarchal social forms.

In her role as a mid-level FMLN combatant, Maria Serrano also exemplifies the liberated female guerrilla. Her marriage to husband José breaks with conventional gender stereotypes, in that she is a fighter whilst he works behind the lines in the FMLN supply chain. Speaking about their marriage, José makes the point that "in a relationship, anything can happen. If it's not the husband who leaves and joins up first, it's the wife. In our case Maria broke away first!” In this account, José does not try and excuse the fact that he is not a combatant, but instead embraces the route Maria has taken into the guerrilla army. Maria also reflects philosophically on her status: "If someone had told me ten years ago that I would be sitting planning military strategy, or even carrying a gun, I would never have believed it. But just to survive, I've learned to do so many things I never imagined I could do." She thinks of her role in the FMLN as a fact of life, a necessity brought about by the great inequality and repression she experienced whilst performing domestic labour. She is therefore liberated from the drudgery of her former life, but has by no means lost her feminine identity: her thirteen year-old daughter Minita talks of feeling her mother's "support" 
every day, and Maria herself admits that when the war is over, "I'm going to change these old boots for the shoes of a lady."

In these various ways, When the Mountains Tremble and Maria's Story argue that participation in guerrilla struggle positively transformed the lives of many Central American women, in spite of the difficulties involved. The films highlight the dialectic that existed in the relationship between women's treatment under the Guatemalan and Salvadoran military regimes - where they were sexualised objects, and the subjects of gruesome sexual violence as a form of political repression - and their comparative liberation after joining the revolution. Whilst life with the guerrillas is not overtly romanticised, these documentaries undoubtedly make the point that a change in gender relations can only come as a part of an upheaval of broader social relations relating to economic equality and democratic freedom. In doing so, they functioned as propaganda for the Guatemalan and Salvadoran revolutions, but they also represented a marked tendency in the solidarity movement to find new and productive relationships between the politics of feminism and anti-interventionism.

\section{$\underline{\text { Conclusion }}$}

Much has been made in the years since 11 September 2001 of the manner in which liberal feminists in the U.S. have reversed the trend documented in this article by fusing gender politics with an explicitly interventionist approach to U.S. foreign policy. In doing so, they have advocated direct military intervention in Afghanistan and Iraq under the guise of "saving brown women" from their nations' patriarchal structures. ${ }^{64}$ As cultural anthropologist Saba Mahmood has argued, a range of contemporary North American feminists, from Susan Sontag and Margaret Atwood to

\footnotetext{
${ }^{64}$ Miriam Cooke, “Saving Brown Women” in Signs 28:1 (Autumn 2002) pp. 468-470.
} 
Barbara Ehrenreich and Katha Pollitt, have fused the tropes of freedom, democracy and gender equality to highlight Islam's mistreatment of women, and to justify the restructuring of Middle Eastern societies along liberal, capitalist lines. ${ }^{65}$

The activism and ideas of the women discussed above provide a challenge to these contemporary forms of interventionist gender politics. They offer an alternative model of feminist international solidarity work that, whilst not without its flaws and contradictions, demonstrates how feminist thinking can be fused with an opposition to U.S. military adventurism in a variety of challenging and inventive ways. In spite of the obvious differences between the activists, intellectuals and filmmakers examined in this paper, their shared concern with the intersections of anti-interventionist and feminist political discourse sheds light on the political and intellectual contexts in which U.S. feminism developed during the 1970s and 1980s. They demonstrate that progressive women's activism did not disappear in the face of the conservative, antifeminist backlash of those decades. Instead, feminists internationalised the scope of their political thinking, entering into conversation with activists in various parts of the Third World. They met at UN-sponsored international conferences, shared ideas, and returned home with fresh approaches to their activism. These ideas percolated movement culture, and informed the intellectual production of figures such as Margaret Randall and Cynthia Enloe, as well as the filmmaking of those involved in When the Mountains Tremble and Maria's Story. Such overtly politicised examples of cultural engagement therefore show how the work of activists, intellectuals and filmmakers overlapped during the 1980s to produce a vibrant culture of dissent that

\footnotetext{
${ }^{65}$ Saba Mahmood, "Feminism, Democracy and Empire: Islam and the War on Terror" in Joan Wallach Scott (ed.), Women's Studies on the Edge (Durham, NC: Duke University press, 2008) p. 82. For excellent analyses of the complicity between feminism and U.S. interventionism, see also Chandra Talpade Mohenty, “U.S. Empire and the Project of Women's Studies: Stories of Citizenship, Complicity and Dissent" in Gender, Place and Culture 13:1 (February 2006) pp. 7-20; Cyra Akila Choudhury, "Globalizing the Margins: Legal Exiles in the War on Terror and Liberal Feminism's War for Muslim Women" in International Review of Constitutionalism 9:2 (2010) pp. 1-29.
} 


\section{U.S. Feminists and Central America in the "Age of Reagan"}

helped to fuse a critique of conservative approaches to women's rights with vigorous opposition to the interventionist foreign policy of the Reagan administration towards Central America. 